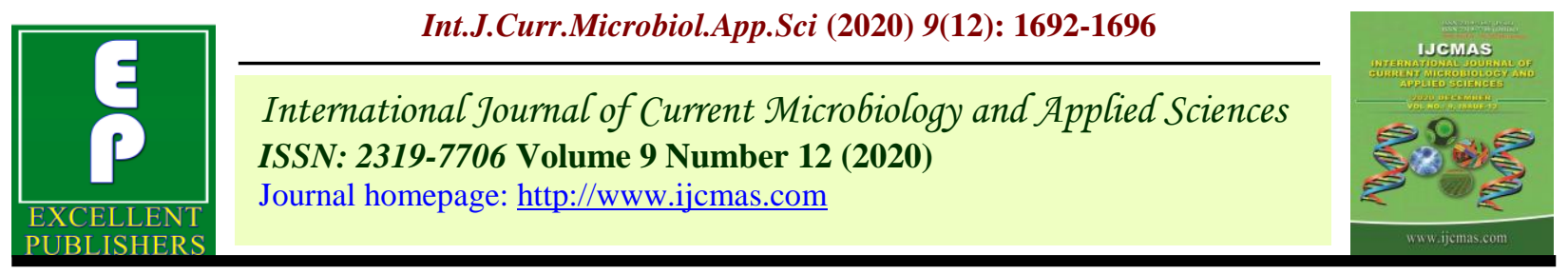

Original Research Article

https://doi.org/10.20546/ijcmas.2020.912.201

\title{
Effect of different levels of Phosphorus and Sulphur on Growth and Yield of Linseed (Linum usitatissimum L.)
}

\author{
Varanasi Varsha Vyas*, Rajesh Singh and Ekta Singh
}

Department of Agronomy, Sam Higginbottom University of Agriculture, Technology and Sciences, Prayagraj- 211007, Uttar Pradesh, India

*Corresponding author

\section{A B S T R A C T}

\section{Keywords}

Linseed, Rabi,

Phosphorus,

Sulphur Growth,

Yield attributes, Oil content

Article Info

Accepted:

12 November 2020

Available Online:

10 December 2020
A field experiment was conducted to determine the effect of different levels of phosphorus and Sulphur on oil and yield of linseed. The experiment was laid out in Randomized Block Design, with 12 treatments, each replicated thrice, in the rabi 2019 with the different levels of Phosphous (30,40,50 $\left.\mathrm{P}_{2} \mathrm{O}_{5} \mathrm{Kg} / \mathrm{ha}\right)$ and Sulphur $(0,15,20,30 \mathrm{~S} \mathrm{Kg} / \mathrm{ha})$ respectively at Crop Research Farm, Department of Agronomy, SHUATS, Prayagraj (U.P). Application of Phosphorus and Sulphur significantly influenced the growth parameters, yield attribute and yield. Addition of $40 \mathrm{~kg} \mathrm{P}_{2} \mathrm{O}_{5}+30 \mathrm{~kg} \mathrm{~S} / \mathrm{ha}$ recorded the highest plant height $(59.47 \mathrm{~cm})$, number of branches $(3.43)$ and maximum dry weight is $(10.86 \mathrm{~g})$ at $80 \mathrm{DAS}$. Whereas, highest number of Capsules/plant (51.24), highest seed yield is $(816.19 \mathrm{Kg} / \mathrm{ha})$ and stover yield is $(2050.40 \mathrm{Kg} / \mathrm{ha})$ recorded with application of $40 \mathrm{Kg} \mathrm{P}_{2} \mathrm{O}_{5}+30 \mathrm{~kg}$ S/ha.

\section{Introduction}

Linseed is an important oil seed crop of central India, locally known as jawas. It has been grown from ancient time for flax (fibre) and for seed purpose, which is rich in oil. It is purely a cool season rabi crop. Temperate and cool climate conditions are best suited for growth. The minimum temperature regime is $100 \mathrm{C}$ while the maximum is $380 \mathrm{C}$. Thus, the main season of growing linseed is October to November depending upon the availability of soil moisture. Early sowing helps the crop to escape the attack of powdery mildew, rust and linseed bud fly in different regions. The crop takes 120-140 days to mature depending on the cultivar. Drought and high temperature at early and seed filling stages are detrimental causing yield and quality. Flax seed contains 23\% 18:3 Omega-3 fatty acids (mostly ALA) and 6\% 18:2 Omega-6 fatty acids. One of the main components of Flax lignin which has plant oestrogen as well as anti-oxidants (flax contains up to 800 times more lignans than 
other plant foods contain). Linseed or flax is an important crop with many uses. Its oil is used in the manufacture of paints, varnish, oil cloth and linoleum. If it contains much linolenic acid and little oleic acid, Oil having much oleic acid. On the other hand is valuable for human consumption, its fibre has been prized for millennia in the production of textiles and coarse twine. In India, linseed is cultivated in 5.25 lakh ha and total production of linseed is 2.12 lakh tones with average productivity of $403 \mathrm{~kg} / \mathrm{ha}$.

Among the nutrients, phosphorus and sulphur play important role in improving the quality and quantity of linseed (Yawalkar et al., 2002). Majority of cultivated area linseed needs fertilization for good yield as phosphrous and sulphur content is low in soil.

Phosphrous stimulates root development and growth in seedling stage. It also stimulates fruit setting and seed formation (Yawalkar et al., 2002). Sulphur involved in chlorophyll formation and encourages vegetative growth. Sulphur is essential for the synthesis of certain amino acids and oils (Das, 1996). Sulphur is essential for protein synthesis as a constituent of amino-acid (Cystine, Cysteine and methionine). It is required for chlorophyll formation and also for the synthesis of oils (Singh et al., 1986 and Aulakh et al., 1989).

Both sulphur uptake and sulphur translocation in linseed crop vary as a function of growth stages and plant part. Application of sulphur significantly increased yield as well as quality (Kumar et al., 2008).

To, fulfil the necessities for sulphur nutrient, it is necessary to supply these to the hungry soil in concentrated and readily available form i.e. fertilizers. It is also essential to know optimum level of sulphur. Though many workers have worked on this aspect but requirement of sulphur vary from soil to soil and place to place. Even agro-climatic conditions have great influence on the sulphur requirement of a crop. Therefore, it is necessary to find out the most beneficial source and level of sulphur from the point of view of yield, nutrient uptake and quality of linseed.

\section{Materials and Methods}

The experiment was carried out during Rabi season of 2019 at Crop Research Farm, Department of Agronomy, Naini Agricultural Institute, SHUATS, Prayagraj (U.P). The soil of the experimental plot was sandy loam in texture, nearly neutral in soil reaction $(\mathrm{pH}$ $7.2)$, low in organic carbon $(0.58 \%)$, medium in available $\mathrm{N}(238 \mathrm{Kg} / \mathrm{ha})$, high in available $\mathrm{P}(32.10 \mathrm{Kg} / \mathrm{ha})$ and low in available $\mathrm{K}(189$ $\mathrm{Kg} / \mathrm{ha}$ ). The treatment consisted of 4 levels of sulphur viz. S1 (0 Kg S/ha), S2 (15 Kg S/ha), S3 (20 Kg S/ha) and S4 (30 Kg S/ha) and 3 levels of phosphorus P1 (30 Kg/ha), P2 (40 $\mathrm{Kg} / \mathrm{ha})$ and $\mathrm{P} 3(50 \mathrm{Kg} / \mathrm{ha})$. There are 12 treatments each replicated thrice. The experiment was laid out in Randomized Block Design. It was sown on 22nd December 2019 with seed rate $\mathrm{Kg} / \mathrm{ha}$ at spacing $30 \mathrm{~cm} \times 10 \mathrm{~cm}$. Recommended doses of nitrogen and potassium were applied.

\section{Results and Discussion}

The growth parameters like plant height, No. of branches and Dry weight of plant were significantly affected by the application of phosphorus and sulphur.

\section{Growth parameters plant height}

Linseed crop fertilized with $40 \mathrm{Kg}$ P2O5 along with $30 \mathrm{Kg} \mathrm{S} / \mathrm{ha}$ resulted significant increase in plant height $(59.47 \mathrm{cms})$ at 80 DAS. The significant increase in plant height with sulphur application might be attributed to direct and indirect involvement of sulphur 
in the photosynthetic process of plant reported by (Jagtap et al., 2003).

\section{Number of branches/plant}

Whereas, linseed fertilized with $40 \mathrm{Kg}$ P2O5 along with $30 \mathrm{Kg}$ S/ha resulted significant increased No. of branches (3.43) at 80 DAS. Maximum number of branches/plant were recorded with the application of $40 \mathrm{~kg}$ Phosphorus and $30 \mathrm{~kg}$ sulphur/ha reported by (Sune et al., 2006) and (Badiyala et al., 1998).

\section{Dry weight (g)}

Linseed fertilized with $40 \mathrm{Kg}$ P2O5 along with $30 \mathrm{Kg}$ S/ha resulted significant increased dry weight $(10.86 \mathrm{~g})$ at $80 \mathrm{DAS}$. Sulphur help in chlorophyll formation and encourages vegetative plant growth. It also increases root growth (Yawalkar et al., 2002) increase in dry matter per plant with application of sulphur might be due to increase in metabolic activity reported by (Jagtap et al., 2003).

$40 \mathrm{~kg}$ phosphorus and $30 \mathrm{~kg}$ Sulphur. Increase in dry matter production per plant might be the result of better growth and a greater number of branches which might have resulted in higher photosynthetic activity and formation of more photosynthate. These results are in confirmation with the findings of (Idnani et al., 1989) and (Jain et al., 1989).

Table.1 Effect of Phosphorus and Sulphur on growth parameters of Linseed (80 DAS)

\begin{tabular}{|c|c|c|c|}
\hline Treatments & $\begin{array}{c}\text { Plant height } \\
\text { (cm) }\end{array}$ & $\begin{array}{c}\text { No. of branches } \\
\text { /plant }\end{array}$ & $\begin{array}{c}\text { Dry weight } \\
\text { (g/plant) }\end{array}$ \\
\hline $\mathrm{T}_{1}-30 \mathrm{~kg} \mathrm{P}_{2} \mathrm{O}_{5}+0 \mathrm{~kg} \mathrm{~S} / \mathrm{ha}$ & 45.52 & 2.63 & 7.39 \\
\hline $\mathrm{T}_{2}-30 \mathrm{~kg} \mathrm{P}_{2} \mathrm{O}_{5}+15 \mathrm{~kg} \mathrm{~S} / \mathrm{ha}$ & 47.23 & 2.71 & 7.52 \\
\hline $\mathrm{T}_{3}-30 \mathrm{~kg} \mathrm{P}_{2} \mathrm{O}_{5}+20 \mathrm{~kg} \mathrm{~S} / \mathrm{ha}$ & 46.57 & 2.76 & 7.90 \\
\hline $\mathrm{T}_{4}-30 \mathrm{~kg} \mathrm{P}_{2} \mathrm{O}_{5}+30 \mathrm{~kg} \mathrm{~S} / \mathrm{ha}$ & 50.71 & 2.80 & 8.02 \\
\hline $\mathrm{T}_{5}-40 \mathrm{~kg} \mathrm{P}_{2} \mathrm{O}_{5}+0 \mathrm{~kg} \mathrm{~S} / \mathrm{ha}$ & 47.99 & 2.84 & 8.24 \\
\hline $\mathrm{T}_{6}-40 \mathrm{~kg} \mathrm{P}_{2} \mathrm{O}_{5}+15 \mathrm{~kg} \mathrm{~S} / \mathrm{ha}$ & 52.10 & 2.88 & 9.51 \\
\hline $\mathrm{T}_{7}-40 \mathrm{~kg} \mathrm{P}_{2} \mathrm{O}_{5}+20 \mathrm{~kg} \mathrm{~S} / \mathrm{ha}$ & 46.67 & 2.93 & 10.72 \\
\hline $\mathrm{T}_{8}-40 \mathrm{~kg} \mathrm{P}_{2} \mathrm{O}_{5}+30 \mathrm{~kg} \mathrm{~S} / \mathrm{ha}$ & 59.47 & 3.43 & 10.86 \\
\hline $\mathrm{T}_{9}-50 \mathrm{~kg} \mathrm{P}_{2} \mathrm{O}_{5}+0 \mathrm{~kg} \mathrm{~S} / \mathrm{ha}$ & 49.79 & 2.93 & 10.51 \\
\hline $\mathrm{T}_{10}-50 \mathrm{~kg} \mathrm{P}_{2} \mathrm{O}_{5}+15 \mathrm{~kg} \mathrm{~S} / \mathrm{ha}$ & 51.26 & 2.95 & 10.56 \\
\hline $\mathrm{T}_{11}-50 \mathrm{~kg} \mathrm{P}_{2} \mathrm{O}_{5}+20 \mathrm{~kg} \mathrm{~S} / \mathrm{ha}$ & 53.09 & 3.07 & 10.63 \\
\hline $\mathrm{T}_{12}-50 \mathrm{~kg} \mathrm{P}_{2} \mathrm{O}_{5}+30 \mathrm{~kg} \mathrm{~S} / \mathrm{ha}$ & 57.12 & 3.37 & 10.84 \\
\hline SEm \pm & 1.37 & 0.03 & 0.03 \\
\hline CD $(p=0.05)$ & 4.01 & 0.09 & 0.09 \\
\hline
\end{tabular}


Table.2 Effect of phosphorus and sulphur on yield parameters of linseed

\begin{tabular}{|c|c|c|c|}
\hline Treatments & Capsules/plant & $\begin{array}{l}\text { Seed yield } \\
\text { (Kg/ha) }\end{array}$ & $\begin{array}{c}\text { Straw yield } \\
\text { (Kg/ha) }\end{array}$ \\
\hline $\mathrm{T}_{1}-30 \mathrm{~kg} \mathrm{P}_{2} \mathrm{O}_{5}+0 \mathrm{~kg} \mathrm{~S} / \mathrm{ha}$ & 43.16 & 632.85 & 1720.92 \\
\hline $\mathrm{T}_{2}-30 \mathrm{~kg} \mathrm{P}_{2} \mathrm{O}_{5}+15 \mathrm{~kg} \mathrm{~S} / \mathrm{ha}$ & 44.54 & 633.99 & 1758.57 \\
\hline $\mathrm{T}_{3}-30 \mathrm{~kg} \mathrm{P}_{2} \mathrm{O}_{5}+20 \mathrm{~kg} \mathrm{~S} / \mathrm{ha}$ & 45.48 & 626.18 & 1736.59 \\
\hline $\mathrm{T}_{4}-30 \mathrm{~kg} \mathrm{P}_{2} \mathrm{O}_{5}+30 \mathrm{~kg} \mathrm{~S} / \mathrm{ha}$ & 46.47 & 608.84 & 1747.13 \\
\hline $\mathrm{T}_{5}-40 \mathrm{~kg} \mathrm{P}_{2} \mathrm{O}_{5}+0 \mathrm{~kg} \mathrm{~S} / \mathrm{ha}$ & 47.70 & 628.42 & 1745.92 \\
\hline $\mathrm{T}_{6}-40 \mathrm{~kg} \mathrm{P}_{2} \mathrm{O}_{5}+15 \mathrm{~kg} \mathrm{~S} / \mathrm{ha}$ & 45.98 & 619.39 & 1769.90 \\
\hline $\mathrm{T}_{7}-40 \mathrm{~kg} \mathrm{P}_{2} \mathrm{O}_{5}+20 \mathrm{~kg} \mathrm{~S} / \mathrm{ha}$ & 48.17 & 651.67 & 1752.70 \\
\hline $\mathrm{T}_{8}-40 \mathrm{~kg} \mathrm{P}_{2} \mathrm{O}_{5}+30 \mathrm{~kg} \mathrm{~S} / \mathrm{ha}$ & 51.24 & 816.19 & 2050.40 \\
\hline $\mathrm{T}_{9}-50 \mathrm{~kg} \mathrm{P}_{2} \mathrm{O}_{5}+0 \mathrm{~kg} \mathrm{~S} / \mathrm{ha}$ & 50.29 & 651.65 & 1755.66 \\
\hline $\mathrm{T}_{10}-50 \mathrm{~kg} \mathrm{P}_{2} \mathrm{O}_{5}+15 \mathrm{~kg} \mathrm{~S} / \mathrm{ha}$ & 50.32 & 692.29 & 1712.82 \\
\hline $\mathrm{T}_{11}-50 \mathrm{~kg} \mathrm{P}_{2} \mathrm{O}_{5}+20 \mathrm{~kg} \mathrm{~S} / \mathrm{ha}$ & 50.70 & 715.96 & 1818.82 \\
\hline $\mathrm{T}_{12}-50 \mathrm{~kg} \mathrm{P}_{2} \mathrm{O}_{5}+30 \mathrm{~kg} \mathrm{~S} / \mathrm{ha}$ & 50.74 & 783.37 & 1976.30 \\
\hline SEm \pm & 0.21 & 11.50 & 25.65 \\
\hline$C D(p=0.05)$ & 0.62 & 33.74 & 75.23 \\
\hline
\end{tabular}

\section{Yield attributes}

Yield attributes and yield were significantly affected by phosphorus and sulphur application. Linseed fertilized with $40 \mathrm{Kg}$ P2O5 along with $30 \mathrm{Kg}$ S/ha resulted significant increased No. of capsules/plant (51.24). Highest number of capsules/plant was recorded with the application of $40 \mathrm{kgs}$ phosphorus and $30 \mathrm{kgs}$ sulphur. The results are in accordance with (Sune et al., 2006). Highest seed yield recorded is $(816.19 \mathrm{Kg} / \mathrm{ha})$ and stover yield is $(2050.40 \mathrm{Kg} / \mathrm{ha})$.

Increase in the seed yield might be due to vigorous growth which might have helped in higher dry production resulting in more photosynthate accumulation in the sink which ultimately reflected interms of higher seed yield reported by (Awasti et al.,1989) and (Vashistha et al.,1993) (Table 1 and 2).

In conclusion, it is inferred from the present investigation that application of $40 \mathrm{Kg}$ P2O5 along with $30 \mathrm{Kg}$ S/ha in addition to the full doses of nitrogen and potassium is recommended for receiving higher growth and yield of Linseed.

\section{References}

Aulakh, M. S., Pasricha, N. S., Azad, A. S. and Ahuja, K. L., (1989). Response of linseed to fertilizer nitrogen, phosphorous and sulphur and their effect on the removal of soil sulphur. Soil Use and Management 5: 194-195.

Awasthi, V. S., Girish Jha, Namdeo, K. N., 
Shukla, N. P. and Rohan, S. 1989. Response of linseed (Linum usitatissimum L.) to nitrogen and phosphorous levels. Indian Journal of Agronomy 34: 432-433.

Badiyala, D., Singh, C. M. and Kumar,S. (1998). Fertilizer management in flax. Indian Journal of Agriculture Science 68: 302-303.

Das, P.C. 1996. Manures and Fertilizers. II Edn. Pp. 5-15.

Idnani, L. K., M. N. Sinha and R. K. Rai, 1989. Phosphorus utilization by linseed (Linum usitatissimum L.) as influenced by weed management. J. Nuclear Agric. and Bio. 18(1): 36-39.

Jagtap, A. G. 2003. Effect of different sources and levels of sulphur on growth and yield of linseed. Unpublished M Sc. Agri. Thesis, Dr. PDKV, Akola.

Jain, V. K., Chauhan, Y. S., Khandekar, M. P., Sharma, R. P. and Yadav, M. S. (1989). Effect of nitrogen and phosphorous on growth and yield of linseed (Linum usitatissimum L.). Indian Journal of Agronomy 34: 122-
124.

Kumar, A., S. Mahendra and R. K. Mehara, 2008. Effect of phosphorus and sulphur on yield and nutrient uptake by groundnut in inceptisols. Asian J. Soil Sci. 3(1): 139-141.

Singh, V., Mehta, V. S. and Singh, P. (1986). Effect of $\mathrm{N}$ and $\mathrm{S}$ on linseed in sandy and clay loam soils. Fertilizer news, 4445.

Sune, V. S., Deshpande, R. M., Khavale, V. S., Bavisker, P. K. and Gurao P. B. (2006). Effect of phosphorus and sulphur Application on growth and yield of linseed (Linum usitatissimum L). Journals of soils and crops $16: 217$ 221.

Vashishtha, P. R. (1993). Influence of Nitrogen, phosphorus and Sulphur application on the yield and oil content of linseed (Linum usitatissimum L.). Indian journal of Agronomy 38: 64-67.

Yawalkar, K. S., J. P. Agarwal and S. Bodke, 2002. Manure and fertilizer. 9th revised Edn. pp. 8-13.

\section{How to cite this article:}

Varanasi Varsha Vyas, Rajesh Singh and Ekta Singh. 2020. Effect of Different Levels of Phosphorus and Sulphur on Oil and Yield of Linseed (Linum usitatissimum L.). Int.J.Curr.Microbiol.App.Sci. 9(12): 1692-1696. doi: https://doi.org/10.20546/ijcmas.2020.912.201 